\title{
Recent Advances in Understanding and Managing
}

\section{Cardiomyopathy [version 1; peer review: 2 approved]}

\author{
Paulino Alvarez1, WH Wilson Tang (DiD1,2 \\ ${ }^{1}$ Department of Cardiovascular Medicine, Heart and Vascular Institute, Cleveland Clinic, Cleveland, Ohio, USA \\ ${ }^{2}$ Center for Clinical Genomics, Cleveland Clinic, Cleveland, Ohio, USA
}

V1 First published: 07 Sep 2017, 6(F1000 Faculty Rev):1659

https://doi.org/10.12688/f1000research.11669.1

Latest published: 07 Sep 2017, 6(F1000 Faculty Rev):1659

https://doi.org/10.12688/f1000research.11669.1

\section{Abstract}

Cardiomyopathy is a disease of the heart muscle leading to abnormal structure or function in the absence of coronary artery disease, hypertension, or valvular or congenital heart disease. Currently, cardiomyopathy is the leading diagnosis of heart transplant patients worldwide. Incorporation of next-generation sequencing strategies will likely revolutionize genetic testing in cardiomyopathy. The use of patient-specific pluripotent stem cell-derived cardiomyocytes for disease modeling and therapeutic testing has opened a new avenue for precision medicine in cardiomyopathy. Stem cell therapy, gene therapy, interfering RNA, and small molecules are actively being evaluated in clinical trials.

\section{Keywords}

cardiomyopathy, heart transplant, cardiomyocytes

\section{Open Peer Review \\ Approval Status \\ 1 2 \\ version 1 \\ 07 Sep 2017 \\ Faculty Reviews are review articles written by the prestigious Members of Faculty Opinions. The articles are commissioned and peer reviewed before publication to ensure that the final, published version is comprehensive and accessible. The reviewers who approved the final version are listed with their names and affiliations.}

1. Barry H Greenberg, University of California San Diego Medical Center, San Diego, USA

2. Hector Ventura, John Ochsner Heart and Vascular Institute, University of Queensland School of Medicine, New Orleans, USA Any comments on the article can be found at the end of the article. 
Corresponding author: WH Wilson Tang (tangw@ccf.org)

Competing interests: The authors declare that they have no competing interests.

Grant information: WT is supported by grants from the National Institutes of Health (R01HL103866, P20HL113452, R01DK106000,

R01HL126827).

The funders had no role in study design, data collection and analysis, decision to publish, or preparation of the manuscript.

Copyright: ( 2017 Alvarez P and Tang WW. This is an open access article distributed under the terms of the Creative Commons

Attribution License, which permits unrestricted use, distribution, and reproduction in any medium, provided the original work is properly cited.

How to cite this article: Alvarez P and Tang WW. Recent Advances in Understanding and Managing Cardiomyopathy [version 1; peer review: 2 approved] F1000Research 2017, 6(F1000 Faculty Rev):1659 https://doi.org/10.12688/f1000research.11669.1

First published: 07 Sep 2017, 6(F1000 Faculty Rev):1659 https://doi.org/10.12688/f1000research.11669.1 


\section{Introduction}

Cardiomyopathy is a disease of the heart muscle leading to abnormal structure or function in the absence of coronary artery disease, hypertension, or valvular or congenital heart disease ${ }^{1}$. Morphological subtypes include dilated cardiomyopathy, hypertrophic cardiomyopathy (HCM), arrhythmogenic right ventricular (RV) cardiomyopathy, left ventricular (LV) non-compaction, and restrictive cardiomyopathy. The global number of deaths and disability attributed to cardiomyopathy and myocarditis has steadily increased $^{2,3}$. Cardiomyopathy represents the leading cause of cardiac transplantation ${ }^{4}$. The hereditary nature of most cardiomyopathies creates an opportunity for early detection through family screening but also has the potential for misdiagnosis ${ }^{5}$. How we classify, detect, and treat cardiomyopathy in 2017 and what is on the horizon are the focus of our review. In addition, infiltrative myocardial disease as an important differential diagnosis will be discussed when appropriate.

\section{Classification}

As stated in the "Report of the 1995 World Health Organization/ International Society and Federation of Cardiology Task Force on the Definition and Classification of Cardiomyopathies", a classification is an attempt to "bridge the gap between ignorance and

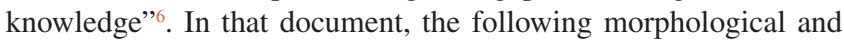
functional subtypes were recognized:

- Dilated cardiomyopathy: characterized by ventricular dilatation and impaired contraction

- HCM: characterized by LV and/or RV hypertrophy, which is usually asymmetric and involves the interventricular septum

- Restrictive cardiomyopathy: characterized by restrictive filling and reduced diastolic volume of either or both ventricles with normal or near-normal systolic function and wall thickness

- Arrhythmogenic RV cardiomyopathy: progressive fibro-fatty replacement of RV myocardium, initially with typical regional and later global right and some LV involvement, with relative sparing of the septum

- Unclassified cardiomyopathies: unclassified cardiomyopathies include a few cases that do not fit readily into any group

The 2006 American Heart Association (AHA) classification divided cardiomyopathies into primary, which are solely or predominantly confined to heart muscle, and secondary cardiomyopathies, which show pathological myocardial involvement as part of generalized systemic (multi-organ) disorders ${ }^{7}$. Primary cardiomyopathies are subclassified into genetic, mixed (genetic and non-genetic), and acquired. In 2007, the European Society of Cardiology proposed a new classification in which each morpho-functional subtype was subclassified according to familial/ genetic and non-familial/non-genetic forms. The familial/genetic forms were subdivided into unidentified gene defect and specific disease subtype, and the non-familial/non-genetic into idiopathic and specific disease subtype ${ }^{8}$. "Specific cardiomyopathies" is used to describe cardiomyopathies associated with specific cardiac or systemic disorders. For example, a recent AHA document reviews diagnostic and treatment strategies for specific cardiomyopathies such as cardiac amyloidosis, cardiotoxins, peripartum cardiomyopathy, cardiac sarcoidosis, myocarditis, autoimmune cardiomyopathy, endocrine and metabolic cardiomyopathies, and genetic cardiomyopathies ${ }^{9}$. Nevertheless, the application of morphological criteria can be misleading because diseases with similar imaging findings can have completely different pathophysiological mechanisms (for example, HCM and Fabry disease) ${ }^{10}$.

The MOGE(S) classification of cardiomyopathies proposes a descriptive phenotype and genotype nosology system that incorporates the following five attributes: morpho-functional phenotype, organ(s) involvement, genetic inheritance pattern, etiological annotation including genetic defect or underlying disease/ substrate, and functional status of the patient and disease process using both the American College of Cardiology/AHA stage and New York Heart Association functional class. The MOGE(S) nosology system is the most recently proposed ${ }^{1}$. The use of a web-based application facilitates the implementation of this classification system (http://moges.biomeris.com/moges.html) (Figure 1).

Because the presence of a morphological abnormality is not synonymous with cardiomyopathy (for example, imaging criteria for LV non-compaction may be seen in more than $10 \%$ of persons free from cardiovascular disease), and the risk of developing genotypepositive and phenotype-negative cardiomyopathy is unknown, the clinician faces major challenges when evaluating an individual patient $^{11,12}$. Quarta et al. recently proposed a framework to navigate this uncertainty ${ }^{13}$. Their major criteria to diagnose cardiomyopathy include "1- Marked morphological abnormalities, clearly outside the limits of physiological remodeling, 2- Clear evidence of global or regional LV (and/or RV) systolic or diastolic dysfunction, or dynamic LV outflow obstruction at rest or on effort, 3- Frequent $(>10,000$ beats per $24 \mathrm{~h}$ ) and repetitive ventricular ectopic beats, which do not subside or tend to increase with exercise and/or are polymorphic, or runs of sustained or nonsustained ventricular tachycardia, 4- Symptoms such as dyspnea, angina, pre-syncopal or syncopal episodes of non-vasovagal nature (particularly if upon or after exertion or after a meal), or reduced performance as assessed by cardiorespiratory testing, 5- A positive genetic test - when available and robust - or specific family history of cardiomyopathy and/or juvenile heart failure or sudden death; if unknown or not investigated, judgment should be suspended until relatives have been screened".

\section{Detection of abnormal structure and function}

Non-invasive diagnostic modalities

Echocardiography is often the first diagnostic modality used when cardiomyopathy is suspected. Although morphological twodimensional echocardiography and ejection fraction are key elements for phenotype characterization, advanced echocardiographic modalities such as tissue Doppler and strain have made possible the detection of early stages of myocardial dysfunction. 

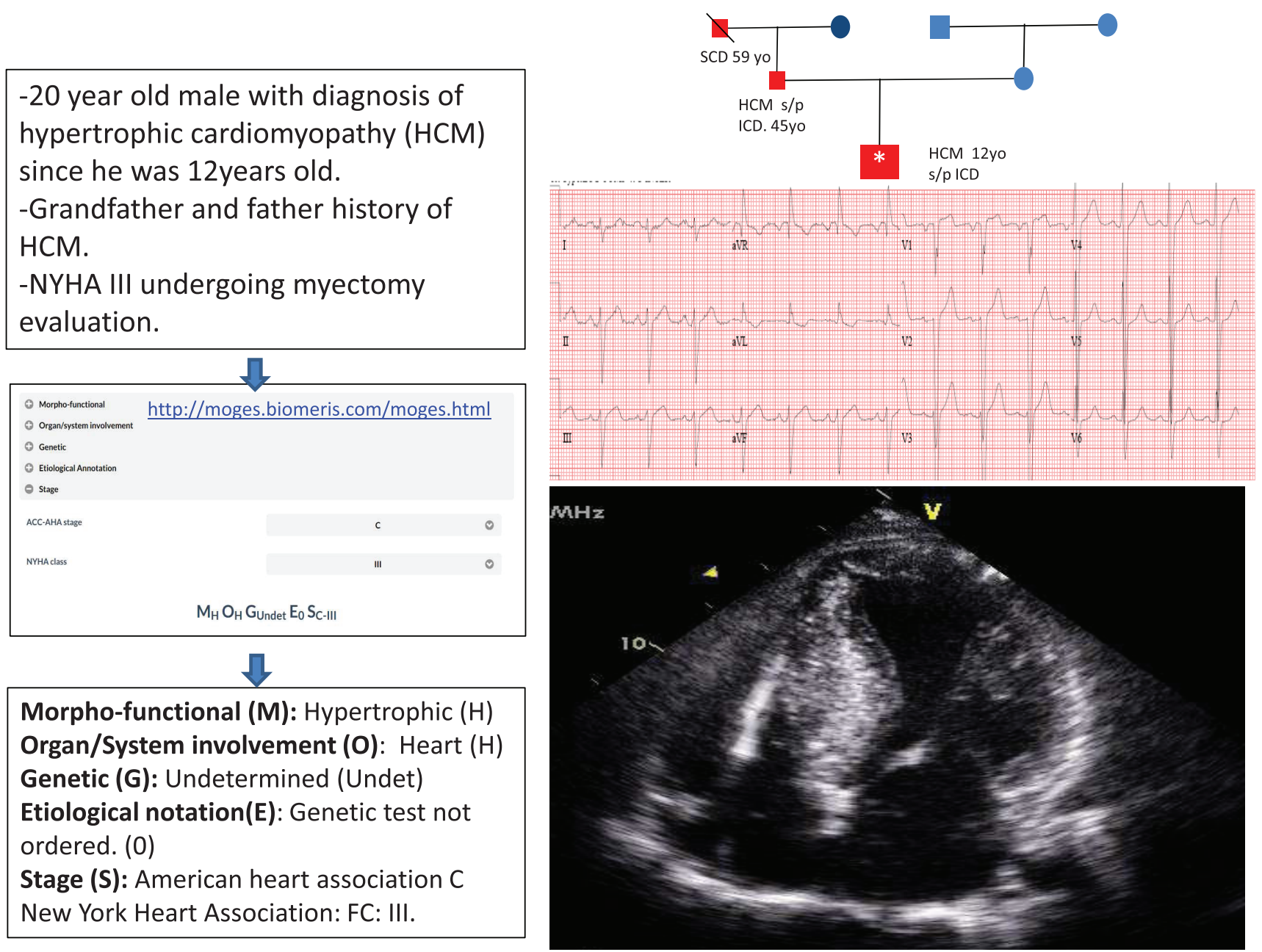

Figure 1. Example of MOGES classification utilization. Family diagram: square, male; circle, female; red, history of sudden cardiac death (SCD) or hypertrophic cardiomyopathy (HCM); blue, no history of SCD or HCM. Index case: *Age at diagnosis or SCD. Since no genotyping was performed, the mode of inheritance cannot be determined with certainty. FC, functional class; ICD, implantable cardioverter defibrillator; NYHA, New York Heart Association; s/p, status post.

Abnormal tissue Doppler signals may help to identify the presence of HCM in the pre-hypertrophic stage and to differentiate athlete's heart from $\mathrm{HCM}^{14,15}$. Machine learning models that incorporate longitudinal strain, among other volumetric and mechanical function variables, may help in the distinction between physiologic and pathologic hypertrophy ${ }^{16}$. In patients with sarcoidosis but without evidence or history of cardiac involvement, impairment of global LV longitudinal strain was associated with increased risk of cardiac events ${ }^{17}$. In patients exposed to anthracyclines, a relative percentage reduction in global longitudinal strain of at least $15 \%$ early during the course of therapy predicts the development of cardiotoxicity ${ }^{18}$. Abnormal regional patterns of strain are useful for the identification of specific cardiomyopathies such as apical sparring usually seen in patients with preserved ejection fraction heart failure due to cardiac amyloidosis or apical compromise in patients with apical $\mathrm{HCM}^{19,20}$. In patients with obstructive HCM refractory to medical therapy who underwent septal myectomy, basal septal (myocardium removed during myectomy) mean systolic strain and diastolic strain rate correlated with in vitro measured myocardial contractile performance $^{21}$. Longitudinal strain and early diastolic strain pre-transplant showed significant correlations with mRNA expression of titin isoforms, sarcoplasmic reticulum $\mathrm{Ca}^{2+}$ ATPase, and phosphorylated phospholamban in dilated cardiomyopathy ${ }^{22}$.

Vector flow mapping, a novel method of Doppler signal analysis, has shown that the cause of systolic anterior motion of the mitral valve and obstruction in HCM is early systolic ejection flow or isovolumetric vortical flow impacting the posterior aspect of the mitral valve and not Venturi forces related to high flows in the LV outflow tract $^{23}$. Also, vortex formation has been correlated with functional capacity in a pilot study ${ }^{24}$. 
Cardiac magnetic resonance imaging has become an integral part of cardiomyopathy evaluation and risk stratification. Apical-basal bundles and mitral valve abnormalities (for example, increased anterior mitral valve length) have emerged as new phenotypic markers of HCM that are observed also in the pre-hypertrophic stage $\mathrm{e}^{25,26}$. Fractal dimension, a parameter used to quantify myocardial muscle trabecular complexity, is increased in HCM mutation carriers without LV hypertrophy ${ }^{27}$. LV structural abnormalities in patients with arrhythmogenic RV dysplasia have also been described with increased frequency ${ }^{28,29}$.

The presence, distribution, and burden of macroscopic myocardial scar tissue as measured by late gadolinium enhancement (LGE) are of particular importance. In a meta-analysis of 2,390 patients with various types of dilated cardiomyopathies, LGE was independently associated with higher risk of sudden cardiac death (SCD) and ventricular arrhythmias ${ }^{30}$. In HCM, for every $10 \%$ increase in LGE, there was a $40 \%$ increase in SCD events. Of particular importance is that, in patients who were considered to be at low risk of SCD by traditional risk stratification systems, the presence of LGE of at least $15 \%$ of the myocardial mass had a five-year risk of SCD of $6 \%{ }^{31}$. In patients with Duchenne muscular dystrophy, the presence of LGE is associated with a progressive decline in LV ejection fraction (LVEF), and the magnitude of this decline is proportional to the number of myocardial segments with $\mathrm{LGE}^{32}$. In patients with cardiac amyloidosis, cardiac magnetic resonance imaging shows a characteristic pattern of global subendocardial LGE; in addition, patients with systemic AL amyloidosis show markedly increased non-contrast $\mathrm{T} 1$ relaxation times in the myocardium when compared with healthy controls and patients with aortic stenosis ${ }^{33,34}$.

Extracellular volume fraction, which includes both diffuse and macroscopic patchy fibrosis using the modified look-locker inversion (MOLLI) recovery method, has been shown to correlate better with regional LV myocardial velocities than ejection fraction in patients with non-ischemic cardiomyopathy ${ }^{35}$. Increased interstitial fibrosis is a marker of subclinical cardiac involvement in patients who are carriers of lamin $\mathrm{A} / \mathrm{C}$ gene mutation ${ }^{36}$.

Recently, in vivo diffusion tensor cardiac magnetic resonance has been shown to characterize the microstructural dynamics by analyzing sheetlet (laminar microstructures 5-10 cardiomyocyte thick) mobility and orientation during the cardiac cycle. Reduced mobility is seen in both dilated cardiomyopathy and HCM. Nevertheless, in HCM, abnormal diastolic conformation is present, whereas abnormal systolic conformation characterizes dilated cardiomyopathy ${ }^{37}$.

The use of four-dimensional (4D) flow $(3 \mathrm{D}+$ time $=4 \mathrm{D})$ allows the generation of $3 \mathrm{D}$ streamlines that permit the analysis of different flow patterns. The application of this technique in patients with HCM, with and without obstruction, revealed abnormal flow patterns in the ascending aorta in both groups. The significance of these findings is unknown ${ }^{38}$.

Cardiac positron emission tomography evaluates the presence of perfusion and metabolic abnormalities. In cardiac sarcoidosis, the coexistence of myocardial perfusion defects and increased focal metabolic activity, which reflects active disease, is associated with increased risk of death and ventricular tachycardia ${ }^{39} .{ }^{99 m}$ Technetium phosphate derivatives can bind to transthyretin in the myocardium and can be used to identify wild-type and mutant transthyretinrelated amyloidosis. If amyloidosis is suspected and a scan is negative, this favors the diagnosis of light-chain amyloidosis ${ }^{40}$.

\section{Invasive diagnostics}

Invasive hemodynamic evaluation is particularly useful to differentiate restriction from constriction. In this case, simultaneous pressure measurements of the right and left ventricles are performed ideally with high-fidelity conductance catheters to evaluate for the presence of enhanced ventricular interaction and systolic area index in the case of constrictive pericarditis. Careful evaluation is necessary to avoid missing the diagnosis of a potentially reversible condition $^{41}$.

\section{Endomyocardial biopsy}

Transvenous endomyocardial biopsy is an invasive procedure with a reported major complication rate (for example, tamponade) of less than $1 \%{ }^{42}$. The importance of tissue-based diagnosis for accurate prognostication in patients with unexplained cardiomyopathy has been known for a long time ${ }^{43}$. The procedure is usually performed by using fluoroscopic guidance, with increasing interest in the use of 3D echocardiography to decrease the chances of RV free wall biopsy ${ }^{44}$. The endomyocardial biopsy sensitivity can reach almost $100 \%$ in amyloidosis or approximately $30 \%$ in focal diseases such as sarcoidosis ${ }^{45,46}$. Usually, RV biopsy is performed, but the biventricular approach has been reported to increase diagnostic yield with a similar major complication rate in very experienced operators $^{47}$. The performance of voltage mapping to guide endomyocardial biopsy has been described to increase diagnostic yield in patients with focal myocardial diseases such as sarcoidosis or lymphocytic myocarditis $^{48}$.

In myocarditis, the use of immunohistochemistry to characterize inflammatory mechanisms, molecular techniques such as polymerase chain reaction to detect viral genomes, and-more recentlythe analysis of non-coding transcripts such as microRNA hold the promise to continue to improve prognostication and treatment in this potentially lethal condition ${ }^{49,50}$. Interestingly, the presence of focal derangement or diffuse lysis of myofilaments observed by electron microscopy in the endomyocardial samples obtained from the posterolateral LV wall of patients with dilated cardiomyopathy admitted with acutely decompensated heart failure was a strong predictor of death or heart failure re-hospitalization during a follow-up period of $4.9 \pm 3.9$ years $^{51}$.

\section{Device therapy/roles of electrophysiology study/ablation} Implantable cardioverter defibrillators are indicated for the prevention of SCD in selected patients with heart failure and reduced ejection fraction and HCM at high risk of sudden death ${ }^{52,53}$. In cardiac sarcoidosis, the use of programmed electrical stimulation may assist in SCD risk stratification ${ }^{54}$. Approximately $30 \%$ of patients will fail to respond to cardiac resynchronization therapy, and many causes or associated factors have been identified (for example, atrial fibrillation and less than $90 \%$ of biventricular pacing $)^{55}$. A novel mechanism to potentially improve cardiac resynchronization response is pacemaker-induced transient asynchrony. Six hours of daily RV 
pacing halted LV dilatation and myocyte dysfunction in a tachycardia-induced cardiomyopathy model in $\operatorname{dogs}^{56}$. The recognition of a significant premature ventricular contraction burden $(>24 \%)$ should increase the suspicion of premature ventricular contraction-induced cardiomyopathy; this is important because ablation of the ectopic foci may lead to improvement of cardiac function ${ }^{57}$.

Electro-anatomic scar patterns differentiate RV outflow tachycardia from arrhythmogenic RV/dysplasia (ARVD) or cardiomyopathy. In ARVD, dominant sub-tricuspid scars with extensions toward the apex and RV outflow tract (RVOT) are seen where, in RVOT, isolated RVOT scar may be seen $^{58}$. The use of electroanatomical mapping to guide endomyocardial biopsy has been previously described ${ }^{48}$.

\section{Genetic evaluation and testing}

Most cardiomyopathies are monogenic disorders. Unexplained cardiomyopathy, family history of SCD or cardiomyopathy, and electrocardiogram suggesting an inherited arrhythmia should trigger genetic evaluation ${ }^{59}$.

The first fundamental step is a family history using a standardized template (for example, https://familyhistory.hhs.gov/FHH/html/ index.html) if possible. Early consultation with genetics professionals is encouraged. It is important to convey the reason for consultation and potential implications to the patient. In cardiomyopathy, the main roles of genetic testing are to aid in the identification of family members at risk for the condition and to inform screening strategies.

In a large study of 312 patients with dilated cardiomyopathy, a truncating titin mutation was present in one-fourth of familial and in $18 \%$ of sporadic cases. Truncating titin mutations were observed in only $1 \%$ and $3 \%$ of patients with $\operatorname{HCM}(n=231)$ and controls $(n=$ 249), respectively ${ }^{60}$.

Coppini et al. have reported that patients with HCM who have a mutation affecting the thin filament are at increased risk of developing LV dysfunction, heart failure, and severe diastolic dysfunction when compared with patients with thick filament mutations ${ }^{61}$. Nevertheless, it is important to recognize that HCM is a disease where gene-phenotype correlations are more notable for their absence than presence.

Studies showing the impact of genotype in prognosis in ARVD/C have been reported. Patients with ARVD/C and carriers of a desmosomal gene mutation have worse outcomes when compared with those with titin mutations ${ }^{62}$. In addition, in a large cohort of patients with ARVD/C who had pathogenic mutations, desmoplakin mutations were overrepresented in patients with $\mathrm{SCD} /$ ventricular fibrillation as a presenting symptom ${ }^{63}$. In the same study, the negative prognostic implications of having more than one pathogenic mutation and male sex were also reported.

Future applications may include the development of genotypespecific therapies, and pilot studies of pharmacologic therapies in the pre-phenotype phase have been completed (see below). If concomitant congenital malformations are present and a chromosomal disorder is suspected, a chromosomal microarray analysis should be considered. When cardiomyopathy is the main feature and genetic abnormalities at the nucleotide level are suspected, several options are available. Gene panels directed to specific morpho-functional phenotypes that screen for pathogenic mutations are available. Results of genetic testing have five categories: pathogenic, likely pathogenic, variables of unknown significance, likely benign, and benign. The diagnostic yield of these panels is variable and ranges from 50 to $60 \%$ in ARVD and from 20 to $30 \%$ in dilated cardiomyopathy ${ }^{64}$. Pan-cardiomyopathy panels have not been shown to increase the diagnostic sensitivity in $\mathrm{HCM}^{65}$. The decrease in cost and turn-over time of next-generation sequencing strategies, including exome (sequences the genes involved in protein synthesis) and whole genome (sequences both coding and non-coding), has led some institutions to adopt this strategy. From a clinical standpoint, one of the main challenges of non-directed second-generation sequencing is the increase in the identification of variants of unknown significance; this is non-actionable genetic information ${ }^{66}$. Nevertheless, recent reports combining these techniques with functional studies show encouraging results in detecting new pathogenic mutations ${ }^{67}$. The creation of large repositories of genetic and phenotypic information, along with powerful analytic techniques, will shape the implementation of next-generation sequencing ${ }^{68}$.

The incorporation of genetic information in epidemiologic studies with long-term follow-up has opened a new chapter in understanding the natural history of disease. Amyloidosis is a systemic disease due to the deposition of misfolded proteins that may affect the heart. There are two main forms of cardiac amyloid disease: AL amyloidosis due to immunoglobulin light chains and transthyretin amyloidosis. Patients with transthyretin may have wild-type (previously called senile amyloidosis) or genetic variants. The V122I variant, where isoleucine is substituted for valine, has a prevalence of approximately $3 \%$ in African-Americans and is the most common point mutation associated with hereditary transthyretin amyloidosis. Carriers of this mutation were believed to have an increased risk of death. In a study that included 3,856 African-Americans, 124 carriers were detected, and over a follow-up period of 21.5 years, those patients were at increased risk of heart failure development, but there were no statistically significant differences in mortality ${ }^{69}$.

Other genetic variants include Val30Met (Any, Portuguese, Spanish) and Thr60Ala (Irish), both of which commonly affect the nerves and the heart. Nevertheless, early cardiac involvement is not as frequent in $\mathrm{Val} 30 \mathrm{Met}^{70}$.

\section{Precision medicine and emerging therapeutic strategies}

Precision medicine is an emerging approach for disease treatment and prevention that takes into account individual variability (genes, environmental factors, and lifestyle) and is of particular relevance for cardiomyopathy ${ }^{71}$. In this regard, the development of transcription factor-mediated reprogramming techniques, which allowed the production of human-induced pluripotent stem cells (hiPSCs), represents a major step forward ${ }^{72}$. Protocols for the production of patient-specific pluripotent stem cell-derived cardiomyocytes (hiPSC-CMs) are available ${ }^{73}$. Applications of hiPSC-CMs 
include disease modeling, regenerative medicine, drug discovery, and toxicity screening ${ }^{74}$. For hiPSC-CMs that carry a mutation in cardiac transcription, factor TBX20 develops phenotypic characteristics of LV non-compaction cardiomyopathy. In this experiment, abnormal transforming growth factor-beta (TGF- $\beta$ ) signaling was detected. Inhibition of TGF- $\beta$ signaling and genomic correction of the TBX20 mutation were sufficient to reverse the phenotype ${ }^{75}$. Using patient-derived hiPSC-CMs, the mechanisms by which titin mutations cause sarcomere insufficiency in dilated cardiomyopathy were explored ${ }^{76}$. In another exciting experiment, hiPSC-CMs from patients who experience doxorubicin cardiac toxicity were more sensitive to in vitro doxorubicin toxicity than hiPSC-CMs of patients who did not experience doxorubicin toxicity. Several mechanisms were identified, including decreased cell viability, impaired mitochondrial function, metabolic derangements, and increased production of reactive oxygen species ${ }^{77}$. This finding suggests that hiPSCCMs could be a potential tool to predict chemotherapy-induced cardiotoxicity.

Mutation silencing therapy in a murine model of HCM has shown that irreversible triggers to phenotypic expression occur early in development $(<6 \text { weeks of life })^{78}$. One of the advantages of detecting genotype-positive phenotype-negative patients is the potential to intervene and alter the trajectory of disease. In a pilot and first-of-its-kind study, 38 patient carriers of pathogenic sarcomere mutations associated with HCM, but without LV hypertrophy, were randomly assigned to diltiazem or placebo. Patients who received diltiazem showed stable LV diameter and mean thickness-to-dimension ratio compared with control patients who showed a decrease and an increase in LV diameter and mean thickness-to-dimension ratio, respectively ${ }^{79}$.

There has been pre-clinical evidence of the potential benefit of renin-angiotensin axis inhibition in modifying the course of HCM in a randomized controlled trial that included 133 patients with obstructive and non-obstructive cardiomyopathy, but the administration of losartan, though well tolerated, did not show significant difference when compared with placebo with regard to the primary endpoint (change in LV mass as measured by computed tomography or cardiac magnetic resonance imaging $)^{80,81}$.

The presence of LGE has been used to identify patients with Duchenne and Becker muscular dystrophies who have normal LVEF but who are at higher risk of developing cardiac dysfunction. In this particular patient population, treatment with eplerenone (Duchenne) and angiotensin-converting enzyme inhibitor (Duchenne and Becker) delayed and attenuated adverse cardiac remodeling 82,83 .

The value of moderate exercise training in selected patients with HCM has been recently evaluated in a pilot randomized trial. After 16 weeks, patients randomly assigned to the unsupervised exercise protocol had a small but significant increase in exercise capacity as measured by cardiopulmonary exercise testing with no significant adverse events ${ }^{84}$. In non-ischemic dilated cardiomyopathy, myocardial blood flow at rest and after cold pressor test improved after 12 weeks of cardiac rehabilitation ${ }^{85}$.

\section{Target therapy/small molecules}

MYK-461, a small molecule which binds to myosin decreasing its ATPase activity in a dose-dependent manner and consequently sarcomere contractility, has been shown to prevent the development of the HCM phenotype in a murine model of HCM if administered early (8-15 weeks of age) in the pre-hypertrophic stage, and it partially reversed structural abnormalities if administered once the hypertrophic phenotype became manifest ${ }^{86}$. The intravenous administration of MYK-461 decreased contractility and eliminated systolic anterior motion of the mitral valve, relieving outflow obstruction in a feline model of $\mathrm{HCM}^{87}$. Initial experience in humans shows encouraging results with a dosedependent reduction of contractility and abolition of LV outflow gradients in two patients. Of note, one patient experienced asystole after receiving the highest dose studied, but it resolved without intervention ${ }^{88}$.

Noonan syndrome and Noonan syndrome with multiple lentigines (formerly LEOPARD syndrome) as other RASopathies are autosomal dominant disorders caused by germline missense mutations of the Ras/mitogen-activated protein kinase (Ras/MAPK) signaling pathway; one of the phenotypic abnormalities is the development of HCM. A hyper-tyrosil phosphorylated form of protein-zero related (PZR) is present in the hearts of mice with those conditions. Yi et al. described that, in a murine model of Noonan syndrome and Noonan syndrome with lentigines, the administration of low-dose dasatinib (tyrosine kinase inhibitor) improves cardiomyocyte contractility, reduces fibrosis, and-if administered in utero-rescues HCM phenotype ${ }^{89}$.

The LMNA gene encodes lamins $\mathrm{C}$ and A that are the major constituents of nuclear lamina, a proteinaceous meshwork that gives structural support to the nucleus and enables correct gene expression and DNA repair. Lamins A and C are generated through alternative splicing ${ }^{90}$. Laminopathies are a diverse group of disorders caused by LMNA gene mutations and the most common one is dilated cardiomyopathy ${ }^{91}$. Current pathophysiological mechanisms of LMNA mutations include increased susceptibility to mechanical stress, altered gene expression, and accumulation of pre-lamin $\mathrm{A}^{92,93}$. The feasibility of alternative splicing modulation with antisense oligonucleotides to increase lamin $\mathrm{C}$ and decrease pre-lamin A accumulation has been successfully tested in fibroblasts of patients with Hutchinson-Gilford progeria syndrome and a mouse model ${ }^{94}$. The recognition of abnormal activation of the MAPK and Akt/mTOR (mammalian target of rapamycin) pathways has led to promising experimental data using protein kinaseinhibitors and mTOR inhibitors, respectively, to block the development of cardiac dysfunction in mouse models of laminopathies ${ }^{95,96}$.

Constitutive activation of mammalian target of rapamycin complex 1 (MTOR-1) by tuberous sclerosis mutations is a recognized mechanism of tumor formation in this syndrome. In a patient with tuberous sclerosis and cardiomyopathy in which phosphorylation of ribosomal protein S6 (marker of MTOR-1 activation) was detected in endomyocardial biopsy, the administration of everolimus (MTOR inhibitor) led to improvement in systolic function and LV dimensions ${ }^{97}$. 


\section{Gene therapy in cardiomyopathy and heart failure}

Increased understanding of the molecular mechanisms of heart failure have led to the recognition of potential targets for gene therapy ${ }^{98}$. Increasing cardiac contractility by targeting molecules related to calcium cycling (sarcoplasmic reticulum $\mathrm{Ca}^{2+}$ ATPase, or SERCA2a) or increasing beta-adrenergic system function (human adenylyl cyclase type 6, or hAC6) and enhancing stem cell tissue repair by increasing the expression of stem cell-derived factor 1 (SDF-1) have undergone clinical trial evaluation ${ }^{99}$. Calcium upregulation by percutaneous administration of gene therapy in patients with cardiac disease (CUPID 2) that included 250 patients with NYHA (New York Heart Association) functional class II-IV and LVEF of not more than $35 \%$ who were randomly assigned to intracoronary infusion of adeno-associated virus loaded with SERCA gene versus placebo failed to achieve the primary endpoint of recurrent events (hospital admission because of heart failure or ambulatory treatment for worsening heart failure) with a median follow-up of 17.5 months. Nevertheless, the absence of significant adverse events is promising and has helped to enhance the interest in this therapeutic strategy ${ }^{100}$. A recent phase II trial has shown a significant increase in LVEF in patients who received intracoronary delivery of adenovirus hAC6 when compared with placebo ${ }^{101}$.

\section{Cell therapy in non-ischemic cardiomyopathy}

Intravenous allogenic mesenchymal stem cells were shown to be safe and effective in improving the 6-minute walk test and quality-of-life measures in patients with non-ischemic cardiomyopathy with a mean LVEF of $31 \%$. There was no evidence of myocardial scar as measured by LGE in patients on maximal medical therapy ${ }^{102}$. In a previous article, trans-endocardial injection of allogenic mesenchymal stem cells was superior to automesenchymal stem cells in terms of efficacy (LVEF improvement and 6-minute walk test) and safety with an extremely low risk of allosensitization $^{103}$. A phase I clinical trial of transplantation of scaffold-free cell sheets derived from autologous muscle to the epicardial surface through left thoracotomy in patients with severe LV dysfunction due to ischemic $(n=15)$ or dilated cardiomyopathy $(\mathrm{n}=12)$ has shown promising results regarding safety with no major procedural adverse events and efficacy with improvement in symptoms, 6-minute walk test, and $\mathrm{LVEF}^{104}$.

\section{New developments in treating amyloidosis}

Novel therapies that block abnormal protein synthesis such as small interfering RNA and antisense oligonucleotides are undergoing phase III clinical trial evaluation in transthyretin amyloidosis, the most common form of cardiac amyloidosis ${ }^{70}$. In light-chain amyloidosis, the use of an amyloid fibril-reactive chimeric monoclonal antibody is undergoing clinical trial evaluation. This approach was shown to be safe in a phase I clinical trial that included six patients with refractory amyloidosis. Those three patients showed organ response: two cardiac and one gastrointestinal $^{105}$.

\section{Immune modulation in heart failure}

Inflammation is a key player in the development and progression of heart failure ${ }^{106}$. Anti- tumor necrosis factor therapy has been shown to be ineffective and even potentially harmful in this patient population in large randomized clinical trials ${ }^{107}$. Non-specific immunomodulation was also unsuccessful in reducing death from any cause and hospitalization from cardiovascular causes ${ }^{108}$. There is increasing interest in the manipulation of the innate immune system $^{109}$. Toll-like receptors, which are the primary receptors of the innate immune system and related molecules (for example, myeloid differentiation 1), constitute attractive targets that are the subject of intense research ${ }^{110,111}$. In addition, the recognition that embryonic-derived macrophages that have anti-inflammatory properties and promote tissue regeneration are replaced in heart failure with monocyte-derived macrophages that have pro-inflammatory properties may open a new pathway to cardiac recovery ${ }^{112}$.

\section{New surgical approaches}

In HCM, surgical septal myectomy often resolves mitral regurgitation related to systolic anterior motion of the mitral valve; nevertheless, some patients need additional mitral valve procedures such as mitral valve repair or replacement ${ }^{113}$. A novel operative technique that consists of trans-aortic cutting of thickened secondary mitral valve chordae seems to be effective in relieving outflow tract obstruction in patients with HCM and mild septal thickness with the advantage of avoiding additional mitral valve procedures ${ }^{114}$. This technique is based on the pathophysiological hypothesis that fibrotic and retracted secondary chordae may cause abnormal tethering of the anterior mitral valve and favor the displacement of the "slack portions of the leaflet (and attached primary chordae) into the LV outflow tract" $" 14$.

\section{Conclusions}

The number of patients affected by cardiomyopathies is increasing. Given the strong genetic basis of many cardiomyopathies, a complete family history is mandatory. Judicious use of cardiac imaging is extremely useful in defining the morpho-functional phenotype, informing prognosis, and detecting subclinical disease. Genetic testing is being increasingly incorporated into clinical practice. MOGES classification provides a good framework to facilitate communication and patient classification. The use of patient-specific pluripotent stem cell-derived cardiomyocytes for disease modeling and therapeutic testing is exciting and hopefully will be incorporated into clinical practice in the near future. Gene therapy, small molecules, small interfering RNA, and antisense oligonucleotides are being tested in clinical trials.

\section{Competing interests}

The authors declare that they have no competing interests.

\section{Grant information}

WT is supported by grants from the National Institutes of Health (R01HL103866, P20HL113452, R01DK106000, and R01HL126827).

The funders had no role in study design, data collection and analysis, decision to publish, or preparation of the manuscript. 
1. Arbustini E, Narula N, Tavazzi L, et al.: The MOGE(S) classification of cardiomyopathy for clinicians. J Am Coll Cardiol. 2014; 64(3): 304-18. PubMed Abstract | Publisher Full Text

2. F Writing Group Members, Mozaffarian D, Benjamin EJ, et al.: Heart Disease and Stroke Statistics-2016 Update: A Report From the American Heart Association. Circulation. 2016; 133(4): e38-360. PubMed Abstract | Publisher Full Text | F1000 Recommendation

3. GBD 2015 Mortality and Causes of Death Collaborators: Global, regional, and national life expectancy, all-cause mortality, and cause-specific mortality for 249 causes of death, 1980-2015: a systematic analysis for the Global Burden of Disease Study 2015. Lancet. 2016; 388(10053): 1459-544. PubMed Abstract | Publisher Full Text | Free Full Text

4. Yusen RD, Edwards LB, Kucheryavaya AY, et al.: The Registry of the International Society for Heart and Lung Transplantation: Thirty-second Official Adult Lung and Heart-Lung Transplantation Report--2015; Focus Theme: Early Graft Failure. J Heart Lung Transplant. 2015; 34(10): 1264-77. PubMed Abstract | Publisher Full Text

5. F Manrai AK, Funke BH, Rehm HL, et al:: Genetic Misdiagnoses and the Potential for Health Disparities. N Engl J Med. 2016; 375(7): 655-65. PubMed Abstract | Publisher Full Text | Free Full Text | F1000 Recommendation

6. Richardson P, McKenna W, Bristow M, et al: Report of the 1995 World Health Organization/International Society and Federation of Cardiology Task Force on the Definition and Classification of cardiomyopathies. Circulation. 1996; 93(5): $841-2$.

PubMed Abstract | Publisher Full Text

7. Maron BJ, Towbin JA, Thiene G, et al: Contemporary definitions and classification of the cardiomyopathies: an American Heart Association Scientific Statement from the Council on Clinical Cardiology, Heart Failure and Transplantation Committee; Quality of Care and Outcomes Research and Functional Genomics and Translational Biology Interdisciplinary Working Groups; and Council on Epidemiology and Prevention. Circulation. 2006; 113(14): 1807-16.

PubMed Abstract | Publisher Full Text

8. Elliott $P$, Andersson $B$, Arbustini $E$, et al:: Classification of the cardiomyopathies: a position statement from the European Society Of Cardiology Working Group on Myocardial and Pericardial Diseases. Eur Heart J. 2008; 29(2): 270-6. PubMed Abstract | Publisher Full Text

9. Bozkurt B, Colvin M, Cook J, et al:: Current Diagnostic and Treatment Strategies for Specific Dilated Cardiomyopathies: A Scientific Statement From the American Heart Association. Circulation. 2016; 134(23): e579-e646. PubMed Abstract | Publisher Full Text

10. Nagueh SF: Fabry disease. Heart. 2003; 89(8): 819-20. PubMed Abstract | Publisher Full Text | Free Full Text

11. Weir-McCall JR, Yeap PM, Papagiorcopulo C, et al:: Left Ventricular Noncompaction: Anatomical Phenotype or Distinct Cardiomyopathy? J Am Coll Cardiol. 2016; 68(20): 2157-65. PubMed Abstract | Publisher Full Text | Free Full Text

12. Maron BJ, Maron MS: The 25-year genetic era in hypertrophic cardiomyopathy: revisited. Circ Cardiovasc Genet. 2014; 7(4): 401-4. PubMed Abstract | Publisher Full Text

13. F Quarta G, Papadakis M, Donna PD, et al.: Grey zones in cardiomyopathies: defining boundaries between genetic and iatrogenic disease. Nat Rev Cardiol. 2017; 14(2): 102-12.

PubMed Abstract | Publisher Full Text | F1000 Recommendation

14. Sen-Chowdhry S, Jacoby D, Moon JC, et al:: Update on hypertrophic cardiomyopathy and a guide to the guidelines. Nat Rev Cardiol. 2016; 13(11): $651-75$.

PubMed Abstract | Publisher Full Text

15. Sheikh N, Papadakis M, Schnell F, et al: Clinical Profile of Athletes With Hypertrophic Cardiomyopathy. Circ Cardiovasc Imaging. 2015; 8(7): e003454. PubMed Abstract | Publisher Full Text

16. F Narula S, Shameer K, Salem Omar AM, et al:: Machine-Learning Algorithms to Automate Morphological and Functional Assessments in 2D Echocardiography. J Am Coll Cardiol. 2016; 68(21): 2287-95. PubMed Abstract | Publisher Full Text | F1000 Recommendation

17. F Joyce E, Ninaber MK, Katsanos S, et al.: Subclinical left ventricular dysfunction by echocardiographic speckle-tracking strain analysis relates to outcome in sarcoidosis. Eur J Heart Fail. 2015; 17(1): 51-62. PubMed Abstract | Publisher Full Text | F1000 Recommendation

18. Plana JC, Galderisi M, Barac A, et al.: Expert consensus for multimodality imaging evaluation of adult patients during and after cancer therapy: a report from the American Society of Echocardiography and the European Association of Cardiovascular Imaging. Eur Heart J Cardiovasc Imaging. 2014; 15(10): 1063-93.

PubMed Abstract | Publisher Full Text | Free Full Text

19. Jan MF, Todaro MC, Oreto L, et al:: Apical hypertrophic cardiomyopathy: Present status. Int J Cardiol. 2016; 222: 745-59.

PubMed Abstract | Publisher Full Text

20. Falk RH, Alexander KM, Liao R, et al:: AL (Light-Chain) Cardiac Amyloidosis: A
Review of Diagnosis and Therapy. J Am Coll Cardiol. 2016; 68(12): 1323-41. PubMed Abstract | Publisher Full Text

21. Dhillon A, Sweet W, Popovic ZB, et al:: Association of noninvasively measured left ventricular mechanics with in vitro muscle contractile performance: a prospective study in hypertrophic cardiomyopathy patients. J Am Heart Assoc. 2014; 3(6): e001269.

PubMed Abstract | Publisher Full Text | Free Full Text

22. Cordero-Reyes AM, Youker K, Estep JD, et al.: Molecular and cellular correlates of cardiac function in end-stage DCM: a study using speckle tracking echocardiography. JACC Cardiovasc Imaging. 2014; 7(5): 441-52. PubMed Abstract | Publisher Full Text

23. Ro R, Halpern D, Sahn DJ, et al.: Vector flow mapping in obstructive hypertrophic cardiomyopathy to assess the relationship of early systolic left ventricular flow and the mitral valve. J Am Coll Cardiol. 2014; 64(19): 1984-95. PubMed Abstract | Publisher Full Text

24. Maragiannis D, Alvarez PA, Schutt RC, et al:: Vortex Formation Time Index in Patients With Hypertrophic Cardiomyopathy. JACC Cardiovasc Imaging. 2016; 9(10): 1229-31.

PubMed Abstract | Publisher Full Text

25. Gruner C, Chan RH, Crean A, et al:: Significance of left ventricular apical-basa muscle bundle identified by cardiovascular magnetic resonance imaging in patients with hypertrophic cardiomyopathy. Eur Heart J. 2014; 35(39): 2706-13. PubMed Abstract | Publisher Full Text

26. F Maron MS, Olivotto I, Harrigan C, et al.: Mitral valve abnormalities identified by cardiovascular magnetic resonance represent a primary phenotypic expression of hypertrophic cardiomyopathy. Circulation. 2011; 124(1): 40-7. PubMed Abstract | Publisher Full Text | F1000 Recommendation

27. Captur G, Lopes LR, Patel V, et al:: Abnormal cardiac formation in hypertrophic cardiomyopathy: fractal analysis of trabeculae and preclinical gene expression. Circ Cardiovasc Genet. 2014; 7(3): 241-8. PubMed Abstract | Publisher Full Text

28. F Rastegar N, Zimmerman SL, Te Riele ASJM, et al.: Spectrum of Biventricular nvolvement on CMR Among Carriers of ARVD/C-Associated Mutations. JACC Cardiovasc Imaging. 2015; 8(7): 863-4.

PubMed Abstract | Publisher Full Text | F1000 Recommendation

29. Calkins $\mathrm{H}$, Tandri $\mathrm{H}$ : Left Ventricular Involvement in ARVD/C: Is It Time to Readjust Our Views? Circ Arrhythm Electrophysiol. 2015; 8(6): 1311-2. PubMed Abstract | Publisher Full Text

30. F Di Marco A, Anguera I, Schmitt M, et al:: Late Gadolinium Enhancement and the Risk for Ventricular Arrhythmias or Sudden Death in Dilated Cardiomyopathy: Systematic Review and Meta-Analysis. JACC Heart Fail. 2017; 5(1): 28-38.

PubMed Abstract | Publisher Full Text | F1000 Recommendation

31. F Chan RH, Maron BJ, Olivotto I, et al:: Prognostic value of quantitative contrast-enhanced cardiovascular magnetic resonance for the evaluation of sudden death risk in patients with hypertrophic cardiomyopathy. Circulation. 2014; 130(6): 484-95.

PubMed Abstract | Publisher Full Text | F1000 Recommendation

32. F Tandon A, Villa CR, Hor KN, et al:: Myocardial fibrosis burden predicts left ventricular ejection fraction and is associated with age and steroid treatmen duration in duchenne muscular dystrophy. J Am Heart Assoc. 2015; 4(4): pii: e001338.

PubMed Abstract | Publisher Full Text | Free Full Text | F1000 Recommendation

33. Maceira AM, Joshi J, Prasad SK, et al:: Cardiovascular magnetic resonance in cardiac amyloidosis. Circulation. 2005; 111(2): 186-93.

PubMed Abstract | Publisher Full Text

34. Karamitsos TD, Piechnik SK, Banypersad SM, et al.: Noncontrast T1 mapping for the diagnosis of cardiac amyloidosis. JACC Cardiovasc Imaging. 2013; 6(4): 488-97.

PubMed Abstract | Publisher Full Text

35. Collins $\mathrm{J}$, Sommerville $\mathrm{C}$, Magrath $\mathrm{P}$, et al:: Extracellular volume fraction is more closely associated with altered regional left ventricular velocities than left ventricular ejection fraction in nonischemic cardiomyopathy. Circ Cardiovasc Imaging. 2014; 8(1): pii: e001998.

PubMed Abstract | Publisher Full Text | Free Full Text

36. Fontana M, Barison A, Botto N, et al:: CMR-verified interstitial myocardial fibrosis as a marker of subclinical cardiac involvement in LMNA mutation carriers. JACC Cardiovasc Imaging. 2013; 6(1): 124-6. PubMed Abstract | Publisher Full Text

37. F Nielles-Vallespin S, Khalique Z, Ferreira PF, et al:: Assessment of Myocardial Microstructural Dynamics by In Vivo Diffusion Tensor Cardiac Magnetic Resonance. J Am Coll Cardiol. 2017; 69(6): 661-76.

PublMed Abstract | Publisher Full Text | F1000 Recommendation

38. Allen BD, Choudhury L, Barker AJ, et al:: Three-dimensional haemodynamics in patients with obstructive and non-obstructive hypertrophic cardiomyopathy assessed by cardiac magnetic resonance. Eur Heart J Cardiovasc Imaging. 2015; 16(1): 29-36.

PubMed Abstract | Publisher Full Text | Free Full Text

39. Blankstein R, Osborne M, Naya M, et al:: Cardiac positron emission tomography 
enhances prognostic assessments of patients with suspected cardiac sarcoidosis. J Am Coll Cardiol. 2014; 63(4): 329-36.

PublMed Abstract | Publisher Full Text | Free Full Text

40. Gertz MA, Dispenzieri A, Sher T: Pathophysiology and treatment of cardiac amyloidosis. Nat Rev Cardiol. 2015; 12(12): 91-102.

PubMed Abstract | Publisher Full Text

41. Witt CM, Eleid MF, Nishimura RA: Diagnosis of constrictive pericarditis obscured by hypertrophic cardiomyopathy: Back to basics. Catheter Cardiovasc Interv. 2015; 86(3): 536-9.

PubMed Abstract | Publisher Full Text

42. From AM, Maleszewski JJ, Rihal CS: Current status of endomyocardial biopsy. Mayo Clin Proc. 2011; 86(11): 1095-102. PubMed Abstract | Publisher Full Text | Free Full Text

43. Felker GM, Thompson RE, Hare JM, et al.: Underlying causes and long-term survival in patients with initially unexplained cardiomyopathy. $N$ Engl $J$ Med. 2000; 342(15): 1077-84.

PubMed Abstract | Publisher Full Text

44. Platts D, Brown M, Javorsky G, et al.: Comparison of fluoroscopic versus real-time three-dimensional transthoracic echocardiographic guidance of endomyocardial biopsies. Eur J Echocardiogr. 2010; 11(7): 637-43. PubMed Abstract | Publisher Full Text

45. Shah KB, Inoue Y, Mehra MR: Amyloidosis and the heart: a comprehensive review. Arch Intern Med. 2006; 166(17): 1805-13. PubMed Abstract | Publisher Full Text

46. Hulten E, Aslam S, Osborne M, et al:: Cardiac sarcoidosis-state of the art review. Cardiovasc Diagn Ther. 2016; 6(1): 50-63. PubMed Abstract | Publisher Full Text | Free Full Text

47. Chimenti $C$, Frustaci A: Contribution and risks of left ventricula endomyocardial biopsy in patients with cardiomyopathies: a retrospective study over a 28-year period. Circulation. 2013; 128(14): 1531-41. PubMed Abstract | Publisher Full Text

48. Liang JJ, Hebl VB, DeSimone CV, et al:: Electrogram guidance: a method to increase the precision and diagnostic yield of endomyocardial biopsy for suspected cardiac sarcoidosis and myocarditis. JACC Heart Fail. 2014; 2(5): $466-73$.

PubMed Abstract | Publisher Full Text | Free Full Text

49. Dominguez F, Kühl U, Pieske B, et al.: Update on Myocarditis and Inflammatory Cardiomyopathy: Reemergence of Endomyocardial Biopsy. Rev Esp Cardiol (Engl Ed). 2016; 69(2): 178-87.

PubMed Abstract | Publisher Full Text

50. KuehlU, Lassner D Gast M, et al: Differential Cardiac MicroRNA Expression Predicts the Clinical Course in Human Enterovirus Cardiomyopathy. Circ Heart Fail. 2015; 8(3): 605-18.

PubMed Abstract | Publisher Full Text

51. Saito T, Asai K, Sato S, et al.: Ultrastructural features of cardiomyocytes in dilated cardiomyopathy with initially decompensated heart failure as a predictor of prognosis. Eur Heart J. 2015; 36(12): 724-32. PubMed Abstract | Publisher Full Text

52. Yancy CW, Jessup M, Bozkurt B, et al:: 2013 ACCF/AHA guideline for the management of heart failure: a report of the American College of Cardiology Foundation/American Heart Association Task Force on Practice Guidelines. J Am Coll Cardiol. 2013; 62(16): e147-239. PubMed Abstract | Publisher Full Tex

53. F Gersh BJ, Maron BJ, Bonow RO, et al.: 2011 ACCF/AHA Guideline for the Diagnosis and Treatment of Hypertrophic Cardiomyopathy: a report of the American College of Cardiology Foundation/American Heart Association Task Force on Practice Guidelines. Developed in collaboration with the American Association for Thoracic Surgery, American Society of Echocardiography, American Society of Nuclear Cardiology, Heart Failure Society of America, Heart Rhythm Society, Society for Cardiovascular Angiography and Interventions, and Society of Thoracic Surgeons. J Am Coll Cardiol. 2011; 58(25): e212-60

PubMed Abstract | Publisher Full Text | F1000 Recommendation

54. Birnie DH, Sauer WH, Bogun F, et al:: HRS expert consensus statement on the diagnosis and management of arrhythmias associated with cardiac sarcoidosis. Heart Rhythm. 2014; 11(7): 1305-23. PubMed Abstract | Publisher Full Text

55. Daubert C, Behar N, Martins RP, et al: Avoiding non-responders to cardiac resynchronization therapy: a practical guide. Eur Heart J. 2017; 38(19): 1463-72. PubMed Abstract | Publisher Full Text

56. Kirk JA, Chakir K, Lee KH, et al.: Pacemaker-induced transient asynchrony suppresses heart failure progression. Sci Transl Med. 2015; 7(319): 319ra207. PubMed Abstract | Publisher Full Text | Free Full Text

57. Latchamsetty R, Bogun F: Premature Ventricular Complex-induced Cardiomyopathy. Rev Esp Cardiol (Engl Ed). 2016; 69(4): 365-9. PubMed Abstract | Publisher Full Text

58. F Venlet J, Piers SR, Jongbloed JD, et al.: Isolated Subepicardial Right Ventricular Outflow Tract Scar in Athletes With Ventricular Tachycardia. J Am Coll Cardiol. 2017; 69(5): 497-507. PubMed Abstract | Publisher Full Text | F1000 Recommendation

59. Burke MA, Cook SA, Seidman JG, et al.: Clinical and Mechanistic Insights Into the Genetics of Cardiomyopathy. J Am Coll Cardiol. 2016; 68(25): 2871-86. PubMed Abstract | Publisher Full Text
60. F Herman DS, Lam L, Taylor MR, et al:: Truncations of titin causing dilated cardiomyopathy. N Engl J Med. 2012; 366(7): 619-28. PubMed Abstract | Publisher Full Text | Free Full Text | F1000 Recommendation

61. Coppini R, Ho CY, Ashley E, et al:: Clinical phenotype and outcome of hypertrophic cardiomyopathy associated with thin-filament gene mutations. J Am Coll Cardiol. 2014; 64(24): 2589-600. PubMed Abstract | Publisher Full Text | Free Full Text

62. Brun F, Barnes CV, Sinagra G, et al:: Titin and desmosomal genes in the natural history of arrhythmogenic right ventricular cardiomyopathy. J Med Genet. 2014; 51(10): 669-76.

PubMed Abstract | Publisher Full Text | Free Full Text

63. Bhonsale A, Groeneweg JA, James CA, et al.: Impact of genotype on clinical course in arrhythmogenic right ventricular dysplasia/cardiomyopathyassociated mutation carriers. Eur Heart J. 2015; 36(14): 847-55. PubMed Abstract | Publisher Full Text

64. F Mital S, Musunuru K, Garg V, et al:: Enhancing Literacy in Cardiovascular Genetics: A Scientific Statement From the American Heart Association. Circ Cardiovasc Genet. 2016; 9(5): 448-67. PubMed Abstract | Publisher Full Text | F1000 Recommendation

65. Alfares AA, Kelly MA, McDermott G, et al.: Results of clinical genetic testing of 2,912 probands with hypertrophic cardiomyopathy: expanded panels offer limited additional sensitivity. Genet Med. 2015; 17(11): 880-8. PubMed Abstract | Publisher Full Text

66. Parikh VN, Ashley EA: Next-Generation Sequencing in Cardiovascular Disease: Present Clinical Applications and the Horizon of Precision Medicine. Circulation. 2017; 135(5): 406-9.

PubMed Abstract | Publisher Full Text | Free Full Text

67. F Hastings R, de Villiers CP, Hooper C, et al:: Combination of Whole Genome Sequencing, Linkage, and Functional Studies Implicates a Missense Mutation in Titin as a Cause of Autosomal Dominant Cardiomyopathy With Features of Left Ventricular Noncompaction. Circ Cardiovasc Genet. 2016; 9(5): 426-35. PubMed Abstract | Publisher Full Text | Free Full Text | F1000 Recommendation

68. Haas J, Frese KS, Peil B, et al.: Atlas of the clinical genetics of human dilated cardiomyopathy. Eur Heart J. 2015; 36(18): 1123-35a. PubMed Abstract | Publisher Full Text

69. F Quarta CC, Buxbaum JN, Shah AM, et al:: The amyloidogenic V122I transthyretin variant in elderly black Americans. N Engl J Med. 2015; 372(1): 21-9.

PubMed Abstract | Publisher Full Text | Free Full Text | F1000 Recommendation

70. Sperry BW, Tang WHW: Amyloid heart disease: genetics translated into disease-modifying therapy. Heart. 2017; 103(11): 812-7. PubMed Abstract | Publisher Full Text

71. F Collins FS, Varmus H: A new initiative on precision medicine. $N$ Engl J Med. 2015; 372(9): 793-5.

PubMed Abstract | Publisher Full Text | Free Full Text | F1000 Recommendation

72. Takahashi K, Yamanaka S: A decade of transcription factor-mediated reprogramming to pluripotency. Nat Rev Mol Cell Biol. 2016; 17(3): 183-93. PubMed Abstract | Publisher Full Text

73. Burridge PW, Diecke S, Matsa E, et al:: Modeling Cardiovascular Diseases with Patient-Specific Human Pluripotent Stem Cell-Derived Cardiomyocytes. Methods Mol Biol. 2016; 1353: 119-30.

PubMed Abstract | Publisher Full Text | Free Full Text

74. Sayed N, Liu C, Wu JC: Translation of Human-Induced Pluripotent Stem Cells: From Clinical Trial in a Dish to Precision Medicine. J Am Coll Cardiol. 2016; 67(18): 2161-76.

PubMed Abstract | Publisher Full Text | Free Full Text

75. F Kodo K, Ong SG, Jahanbani F, et al.: iPSC-derived cardiomyocytes reveal abnormal TGF- $\beta$ signalling in left ventricular non-compaction cardiomyopathy. Nat Cell Biol. 2016; 18(10): 1031-42.

PubMed Abstract | Publisher Full Text | Free Full Text | F1000 Recommendation

76. Hinson JT, Chopra A, Nafissi N, et al.: HEART DISEASE. Titin mutations in iPS cells define sarcomere insufficiency as a cause of dilated cardiomyopathy. Science. 2015; 349(6251): 982-6.

PubMed Abstract | Publisher Full Text | Free Full Text

77. F Burridge PW, Li YF, Matsa E, et al:: Human induced pluripotent stem cellderived cardiomyocytes recapitulate the predilection of breast cancer patients to doxorubicin-induced cardiotoxicity. Nat Med. 2016; 22(5): 547-56. PubMed Abstract | Publisher Full Text | Free Full Text | F1000 Recommendation

78. F Cannon L, Yu ZY, Marciniec T, et al:: Irreversible triggers for hypertrophic cardiomyopathy are established in the early postnatal period. J Am Coll Cardiol. 2015; 65(6): 560-9.

PubMed Abstract | Publisher Full Text | F1000 Recommendation

79. $\mathrm{F} \mathrm{Ho} \mathrm{CY,} \mathrm{Lakdawala} \mathrm{NK,} \mathrm{Cirino} \mathrm{AL,} \mathrm{et} \mathrm{al::} \mathrm{Diltiazem} \mathrm{treatment} \mathrm{for} \mathrm{pre-clinical}$ hypertrophic cardiomyopathy sarcomere mutation carriers: a pilot randomized trial to modify disease expression. JACC Heart Fail. 2015; 3(2): 180-8. PubMed Abstract | Publisher Full Text | Free Full Text | F1000 Recommendation

80. F Axelsson A, Iversen K, Vejlstrup N, et al.: Efficacy and safety of the angiotensin II receptor blocker losartan for hypertrophic cardiomyopathy: the INHERIT randomised, double-blind, placebo-controlled trial. Lancet Diabetes Endocrinol. 2015; 3(2): 123-31.

PubMed Abstract | Publisher Full Text | F1000 Recommendation 
81. Cooper RM, Stables RH: Can RAS inhibitors affect the course of hypertrophic cardiomyopathy? Lancet Diabetes Endocrinol. 2015; 3(2): 95-6. PubMed Abstract | Publisher Full Text

82. F Silva MC, Magalhães TA, Meira ZM, et al:: Myocardial Fibrosis Progression in Duchenne and Becker Muscular Dystrophy: A Randomized Clinical Trial. JAMA Cardiol. 2017; 2(2): 190-9. PubMed Abstract | Publisher Full Text | F1000 Recommendation

83. F Raman SV, Hor KN, Mazur W, et al:: Eplerenone for early cardiomyopathy in Duchenne muscular dystrophy: a randomised, double-blind, placebocontrolled trial. Lancet Neurol. 2015; 14(2): 153-61. PubMed Abstract | Publisher Full Text | Free Full Text | F1000 Recommendation

84. F Saberi S, Wheeler M, Bragg-Gresham J, et al.: Effect of Moderate-Intensity Exercise Training on Peak Oxygen Consumption in Patients With Hypertrophic Cardiomyopathy: A Randomized Clinical Trial. JAMA. 2017; 317(13): 1349-57. PubMed Abstract | Publisher Full Text | Free Full Text | F1000 Recommendation

85. F Legallois D, Belin A, Nesterov SV, et al.: Cardiac rehabilitation improves coronary endothelial function in patients with heart failure due to dilated cardiomyopathy: A positron emission tomography study. Eur J Prev Cardiol. 2016; 23(2): 129-36.

PubMed Abstract | Publisher Full Text | F1000 Recommendation

86. F Green EM, Wakimoto H, Anderson RL, et al:: A small-molecule inhibitor of sarcomere contractility suppresses hypertrophic cardiomyopathy in mice. Science. 2016; 351(6273): 617-21.

PubMed Abstract | Publisher Full Text | Free Full Text | F1000 Recommendation

87. Stern JA, Markova S, Ueda Y, et al:: A Small Molecule Inhibitor of Sarcomere Contractility Acutely Relieves Left Ventricular Outflow Tract Obstruction in Feline Hypertrophic Cardiomyopathy. PLoS One. 2016; 11(12): e0168407. PubMed Abstract | Publisher Full Text | Free Full Text

88. Maron M, Ashley E, Blok T, et al.: Abstract 16842: Obstructive Hypertrophic Cardiomyopathy: Initial Single Ascending Dose Data in Healthy Volunteers and Patients. Circulation. 2016; 134(Suppl 1): A16842.

Reference Source

89. F Yi JS, Huang Y, Kwaczala AT, et al.: Low-dose dasatinib rescues cardiac function in Noonan syndrome. JCl Insight. 2016; 1(20): e90220. PubMed Abstract | Publisher Full Text | Free Full Text | F1000 Recommendation

90. Brayson $\mathrm{D}$, Shanahan $\mathrm{CM}$ : Current insights into LMNA cardiomyopathies: Existing models and missing LINCs. Nucleus. 2017; 8(1): 17-33. PubMed Abstract | Publisher Full Text | Free Full Text

91. Brodsky GL, Muntoni F, Miocic S, et al:: Lamin A/C gene mutation associated with dilated cardiomyopathy with variable skeletal muscle involvement Circulation. 2000; 101(5): 473-6.

PubMed Abstract | Publisher Full Text

92. Lanzicher T, Martinelli V, Puzzi L, et al:: The Cardiomyopathy Lamin A/C D192G Mutation Disrupts Whole-Cell Biomechanics in Cardiomyocytes as Measured by Atomic Force Microscopy Loading-Unloading Curve Analysis. Sci Rep. 2015; 5: 13388.

PubMed Abstract | Publisher Full Text | Free Full Text

93. Davies BS, Barnes RH 2nd, Tu Y, et al:: An accumulation of non-farnesylated prelamin A causes cardiomyopathy but not progeria. Hum Mol Genet. 2010; 19(13): 2682-94

PubMed Abstract | Publisher Full Text | Free Full Text

94. Lee JM, Nobumori C, Tu Y, et al:: Modulation of LMNA splicing as a strategy to treat prelamin A diseases. J Clin Invest. 2016; 126(4): 1592-602. PubMed Abstract | Publisher Full Text | Free Full Text

95. Wu W, Muchir A, Shan J, et al:: Mitogen-activated protein kinase inhibitors improve heart function and prevent fibrosis in cardiomyopathy caused by mutation in lamin A/C gene. Circulation. 2011; 123(1): 53-61. PubMed Abstract | Publisher Full Text | Free Full Text

96. Choi JC, Muchir A, Wu W, et al:: Temsirolimus activates autophagy and ameliorates cardiomyopathy caused by lamin A/C gene mutation. Sci Trans/ Med. 2012; 4(144): 144ra102.

PubMed Abstract | Publisher Full Text | Free Full Text

97. Koyama M, Yano T, Kikuchi K, et al.: Everolimus-responsive dilated cardiomyopathy in tuberous sclerosis. Eur Heart J. 2015; 36(34): 2338. PubMed Abstract | Publisher Full Text
98. Hajjar RJ: Potential of gene therapy as a treatment for heart failure. J Clin Invest. 2013; 123(1): 53-61.

PubMed Abstract | Publisher Full Text | Free Full Text

99. Hulot J, Ishikawa K, Hajjar RJ: Gene therapy for the treatment of heart failure: promise postponed. Eur Heart J. 2016; 37(21): 1651-8. PubMed Abstract | Publisher Full Text | Free Full Text

100. F Greenberg B, Butler J, Felker GM, et al.: Calcium upregulation by percutaneous administration of gene therapy in patients with cardiac disease (CUPID 2): a randomised, multinational, double-blind, placebo-controlled, phase 2b trial. Lancet. 2016; 387(10024): 1178-86. PubMed Abstract | Publisher Full Text | F1000 Recommendation

101. F Hammond HK, Penny WF, Traverse JH, et al:: Intracoronary Gene Transfer of Adenylyl Cyclase 6 in Patients With Heart Failure: A Randomized Clinical Trial. JAMA Cardiol. 2016; 1(2): 163-71.

PubMed Abstract | Publisher Full Text | Free Full Text | F1000 Recommendation

102. F Butler J, Epstein SE, Greene SJ, et al.: Intravenous Allogeneic Mesenchyma Stem Cells for Nonischemic Cardiomyopathy: Safety and Efficacy Results of a Phase II-A Randomized Trial. Circ Res. 2017; 120(2): 332-40. PubMed Abstract | Publisher Full Text | F1000 Recommendation

103. F Hare JM, DiFede DL, Rieger AC, et al:: Randomized Comparison of Allogeneic Versus Autologous Mesenchymal Stem Cells for Nonischemic Dilated Cardiomyopathy: POSEIDON-DCM Trial. J Am Coll Cardiol. 2017; 69(5): 526-37.

PubMed Abstract | Publisher Full Text | Free Full Text | F1000 Recommendation

104. F Miyagawa S, Domae K, Yoshikawa Y, et al.: Phase I Clinical Trial of Autologous Stem Cell-Sheet Transplantation Therapy for Treating Cardiomyopathy. J Am Heart Assoc. 2017; 6(4): pii: e003918. PubMed Abstract | Publisher Full Text | Free Full Text | F1000 Recommendation

105. Langer AL, Miao S, Mapara M, et al:: Results of Phase I Study of Chimeric FibrilReactive Monoclonal Antibody 11-1F4 in Patients with AL Amyloidosis. Blood. 2015; 126(23): 188 Reference Source

106. Anker SD, von Haehling S: Inflammatory mediators in chronic heart failure: an overview. Heart. 2004; 90(4): 464-70. PubMed Abstract | Publisher Full Text | Free Full Text

107. Anker SD, Coats AJ: How to RECOVER from RENAISSANCE? The significance of the results of RECOVER, RENAISSANCE, RENEWAL and ATTACH. Int $J$ Cardiol. 2002; 86(2-3): 123-30. PubMed Abstract | Publisher Full Text

108. Torre-Amione G, Bourge RC, Colucci WS et al: A study to assess the effects of a broad-spectrum immune modulatory therapy on mortality and morbidity in patients with chronic heart failure: the ACCLAIM trial rationale and design. Can J Cardiol. 2007; 23(5): 369-76. PubMed Abstract | Publisher Full Text | Free Full Text

109. Mann DL: Innate immunity and the failing heart: the cytokine hypothesis revisited. Circ Res. 2015; 116(7): 1254-68. PubMed Abstract | Publisher Full Text | Free Full Text

110. Yang $Y, L v J$, Jiang $S$, et al.: The emerging role of Toll-like receptor 4 in myocardial inflammation. Cell Death Dis. 2016; 7: e2234. PubMed Abstract | Publisher Full Text | Free Full Text

111. F Xiong X, Liu Y, Mei Y, et al.: Novel Protective Role of Myeloid Differentiation 1 in Pathological Cardiac Remodelling. Sci Rep. 2017; 7: 41857. PubMed Abstract | Publisher Full Text | Free Full Text | F1000 Recommendation

112. Lavine KJ, Epelman S, Uchida K, et al:: Distinct macrophage lineages contribute to disparate patterns of cardiac recovery and remodeling in the neonatal and adult heart. Proc Natl Acad Sci U S A. 2014; 111(45): 16029-34. PubMed Abstract | Publisher Full Text | Free Full Text

113. $\mathrm{F}$ Hong JH, Schaff HV, Nishimura RA, et al:: Mitral Regurgitation in Patients With Hypertrophic Obstructive Cardiomyopathy: Implications for Concomitant Valve Procedures. J Am Coll Cardiol. 2016; 68(14): 1497-504. PubMed Abstract | Publisher Full Text | F1000 Recommendation

114. F Ferrazzi P, Spirito $\mathrm{P}$, lacovoni A, et al:: Transaortic Chordal Cutting: Mitral Valve Repair for Obstructive Hypertrophic Cardiomyopathy With Mild Septal Hypertrophy. J Am Coll Cardiol. 2015; 66(15): 1687-96. PubMed Abstract | Publisher Full Text | F1000 Recommendation 


\section{Open Peer Review}

\section{Current Peer Review Status:}

\section{Editorial Note on the Review Process}

Faculty Reviews are review articles written by the prestigious Members of Faculty Opinions. The articles are commissioned and peer reviewed before publication to ensure that the final, published version is comprehensive and accessible. The reviewers who approved the final version are listed with their names and affiliations.

\section{The reviewers who approved this article are:}

\section{Version 1}

\section{Hector Ventura}

Department of Cardiovascular Diseases, John Ochsner Heart and Vascular Institute, University of Queensland School of Medicine, New Orleans, LA, USA

Competing Interests: No competing interests were disclosed.

\section{Barry H Greenberg}

Department of Medicine, Division of Cardiovascular Medicine, University of California San Diego Medical Center, San Diego, California, USA

Competing Interests: No competing interests were disclosed.

The benefits of publishing with F1000Research:

- Your article is published within days, with no editorial bias

- You can publish traditional articles, null/negative results, case reports, data notes and more

- The peer review process is transparent and collaborative

- Your article is indexed in PubMed after passing peer review

- Dedicated customer support at every stage

For pre-submission enquiries, contact research@f1000.com 